attributing Divinity and infallibility to contingent human interpretations. It also stresses that all essential principles, values and laws should be directly derived from the Qur'ān without contradicting it (i.e. no other source, like hadīth, ijma ' etc., should be allowed to override the Qur'ān). Muslims should avoid holding ahā $\bar{d} \bar{t} t h$ at par with the Qur'ān and new laws should be formulated according to a $s h \bar{u} r \bar{a}$-based, representative process.

The essence of this reformative work lies in its attempt to institute a fresh approach to Islamic law and Islamic jurisprudence, one that is harmonious with the Qur'ân and Sunnah as well as real-life experience. At the close of the book is a bibliography beneficial for those readers who wish to undertake further research in the field. This book undoubtedly makes a significant contribution to reformist literature in Islamic Jurisprudence by thoroughly discussing important and problematical issues regarding the source material, both primary and secondary. In toto, the book serves as an essential guide for the common reader for understanding the problems Muslims face in contemporary times, the limitations of legalistic fiqh when addressing these problems, and the need for a value-oriented (or maqāsid-based) approach to Islamic jurisprudence.

\title{
Dr. Mohd Daud Bakar, Shariah Minds in Islamic Finance
}

(Kuala Lumpur: Amanie Media), pp. xl + 322

ISBN: 9788671378908

\section{by Yasushi Suzuki, Ritsumeikan Asia Pacific University, Japan}

Having reflected on the author's 20 years of experience as a member, and even chairman, of many Shariah boards around the globe, this book offers a pioneering and insightful look at the inner workings of 'Shariah minds', including how Shariah scholars respond to innovation and how they deal with bottleneck issues within a contemporary regulatory framework. This book enlightens and inspires all the stakeholders in Islamic finance, including Shariah scholars and other professionals in Islamic finance, as well as junior scholars aiming to become Shariah scholars and even ordinary persons on the street, about the importance of attaining knowledge of real experience and practice. Undoubtedly, this book is highly recommended for all stakeholders in Islamic finance.

The book begins with a Preface and 'Monologue of a Shariah advisor' which, upon the author's strong motivation and solid resolution, invites us to share in the Shariah knowledge he has accumulated throughout his career in order to "say goodbye to linear thinking and to welcome exponential thinking," and thereby push the industry of Islamic finance forward. 
Chapter 1 explains the minimum level of knowledge necessary to make a person a Shariah scholar in Islamic finance. While admitting the validity of contributions by non-Shariah qualified or trained members of the Shariah board, the author insists that only qualified and trained Shariah scholars are eligible to undertake the great responsibility of issuing a fatwa. In that context, the author raises three rules to be a Shariah scholar: first, to acknowledge that he/she is working in an environment that is not perfect but requires Shariah solutions; second, he/she has to be cognisant that Shariah scholars do not work in isolation; and thirdly, the most important aspect is to possess 'humility'. Good intellectual knowledge of both the Shariah and contemporary finance, in addition to a good personality, are also emphasised.

Chapter 2 describes the role of Shariah scholars in the industry of Islamic finance. In the main, these scholars provide assurance of Shariah compliance. The author describes the real working process of Shariah boards in order to draw a description of Shariah compliance as an apparatus of 'prevention'.

Chapter 3 outlines what stakeholders expect from Shariah scholars. In particular, this chapter critically assesses the seemingly naive perspective of Muslim 'perfectionist' economists concerning the so-called 'murabahah syndrome' (the conservative credit portfolio strategy used by Islamic banks). The author gives a warning that Islamic economics advocates "wealth distribution' while forgetting a much more important element, which is 'wealth creation'. This chapter also refers to the concept of Shariah governance for Shariah scholars themselves.

Chapter 4 explains why the industry needs Shariah scholars. The author insists that the idea behind having a Shariah board is to provide third party assurance (i.e. a proper check and balance) that Shariah compliance is not being compromised. A Shariah board is therefore expected to provide a Shariah endorsement of the products offered by Islamic financial institutions.

Chapter 5 answers the question of how a Shariah scholar understands and scrutinises financial products. In Bakar's view, Shariah advice is a daily learning process, where experiences are stored up in the brains of scholars for future use, consequently contributing to Shariah solutions for the future development of the Islamic finance industry.

Chapter 6 refers to the different methodologies (disciplines) used by Shariah scholars and other professionals (in particular philosophers of Islamic economics and Muslim economists). The author counters the view that Shariah scholars are simply the 'Shariah-compliant' proponents of products that merely mimic their conventional equivalents. The author insists that Shariah scholars would welcome and praise any move towards developing totally new structures and behaviours for Islamic financial products. 
Chapter 7 explains how Shariah minds should deal with both Shariah rulings (which are Divine) and fiqh rulings (which are human in character). The author refers to the process of ijtihad, or using one's best endeavours to arrive at the intended rulings of Allah the Almighty.

Chapter 8 describes the potential conflicts of interest, as well as the "huge paradox," underlying the fact that Shariah boards are appointed and remunerated by the financial institutions they are supposed to monitor. In this chapter, the author again casts doubt on the naive conclusion reached by Muslim economists that equity-based financing be prioritised over debt-based financing upon the assumption that mudarabah and musharaka financing can be provided on a large scale without affecting the capital adequacy requirement.

Chapter 9 introduces the matrix of Shariah scholar assessment. This chapter also explains the importance of coaching and mentoring young and forthcoming scholars.

Chapter 10 describes the contributions Shariah scholars have made to the Islamic finance industry as a whole. These contributions include: installing general 'confidence' across all stakeholders in the industry; establishing a more robust Shariah compliance process; and effectively branding Islamic finance by undertaking the role of 'global ambassadors'.

In chapter 11, the author talks about the future of Shariah scholarship in Islamic finance, the need for dedicated coaching for junior scholars, and the development of a clearer career path for Shariah professionals. In chapter 12, the author elaborates further on this last point by referring to his own experiences before, and in chapter 13, rounding off the book by sharing his life and work as a global Shariah advisor.

In sum, this book attempts to bridge the divide between the "temporary solution approach' for the needs of contemporary Muslim society and the latter society's 'perfectionists'. The author hopes for a future series of 'exponential achievements' in the world of Islamic finance, built upon the sharing of proper knowledge amongst stakeholders.

Unlike conventional banks, Islamic banks must absorb not just credit risk but also the risk associated with Shariah compliance. In theory, the profit (or the margin of security) earned by Islamic banks has to cover the necessary time and effort - what economists term, the 'transaction costs' - of maintaining their reputations as prudent Shariah compliant lenders. In economics, 'transaction cost' is defined as the economic equivalent of 'friction' in physical systems. This book opens our eyes to how Shariah scholars with the proper 'Shariah minds' built upon solid foundations of realism can act as a 'lubricant' for running the 'nervous system' of Islamic finance.

As Bakar points out, in practice the current mode of profit-and-loss 
sharing provides an idea of the difficulty in assuming equity-based financing. It is impractical to expect the acceleration of participatory financing without preserving much higher security margins to cover further profit-and-loss risk sharing. Shariah scholars, the regulatory authorities and other professionals need to design an appropriate financial architecture which can create different (and socially acceptable) levels of margin opportunities for Islamic banks. 'Shariah minds' will be a key part of this design. Designing an appropriate financial architecture with the proper Shariah minds will constitute the exercising of ijtihad. Indeed, in my view, the publication of this book is in itself a highly laudable example of ijtihad. 